\title{
アメリカ合衆国におけるヒストリック・ディストリクト制度の 現状の法的論点に対する考察 \\ AN ANALYSIS ON THE CURRENT LEGAL ISSUES OF HISTORIC DISTRICTS IN THE UNITED STATES OF AMERICA
}

\author{
窪田严矢*, 西村幸夫** \\ Aya KUBOTA and Yukio NISHIMURA
}

\begin{abstract}
The institution of historic districts is the main tool of preservation planning in the USA. Its current legal issues can be summarized as the following four points: 1) demolition by neglect, 2) establishment of legal standards for design review, 3) freedom of speech for architects and owners, and 4) reasonable relations with other fields. Through democratic procedures emphasizing the openness of public meetings and the selection of commissioners, more sophisticated methods can be exploited.
\end{abstract}

Keywords: Historic Districts, United States of America, taking, historic preservation, freedom of speech, design review ヒストリック・ディストリクト、アメリカ合衆国、テイキング、歴史環境保全、表現の自由、デザイン・レビュー

\section{1. 研究の背景と目的}

アメリカ合衆国（以下アメリカ）での主要な保全手法はヒストリ ック・ディストリクト（Historic District、以下 HD）となってい る'。

本論文では、都市保全の先進事例であるアメリカの HD、特にそ の動態的な㻴境保全手法としての側面に着目し、現状の法的論点を 整理したうえで (第二章から第五章)、今後の展望を考察する（第 六章)。

まず「2. HD とテイキング」では HD 規制によって生じる、個 人に対する経済的負担などに対する考え方をテイキングに関連する 判決を中心にして考察する。「3. 台理的な基準の確立」においては、 実際にHDによって規制を行うにあたって、必要とされる基淮に ついて、「4. 表現の自由」では HD 内のデザイン審査と表現の自 由という基本的権利か满立するか否かについて考察する。15. 他の 法律との調整」では、以上、現在、HD を巡って特に論点とさ㧈て いる四つの点に関する考察を「6. まとめ」として整理し、普遍的 な都市保全のあり方に対する示唆を得ることを目的とする。 なお、本論文で「HD」とは行政（特に地方自治体）によって地 区の歴史に基づいた何らかの特性が認められ、そ打を保全するため に指定さ扒た地区を指し、「歴史的建築物」とは同様の建築物を指
す。両者とも取り壊しや改築、新築等において所有者の同意なしに 法的拘束力のある制限やデザイン審查が行わ扎るのが一般的である。 またアメリカの裁判所制度は、連邦と州が基本的には独立してい るものの、憲法に関連するものについては連邦最高裁判所に上訴す る経路が確保さ扒ており、同時に連邦最高裁の判決が他の裁判所に 対して絶対的な拘束力を持つ。この違憲か否かの判断は、行政の規 制行為などに関連して、最も重大な影響を持っている。本論文では 連邦最高裁に限って明記し、連邦地方裁判所や州裁判所などは併せ て地方裁判所として扱うこととする。

\section{HDとテイキング}

\section{1 テイキングに抵触する可能性のある諸点}

テイキング条項とは連邦修正憲法第 5 条と 14 条に基づいて、不 台理であったり、個人に過度の経済的負担となるような、政府の行 為から私有財産を守ることを目的としている。テイキングと判断さ 扎た場合には、正当な補償が行打扎るか、政府の当該行為が無効と なる。

テイキングが認めら扎るのは、1)規制の目的が不合理であるとき、 あるいは、合理的であっても規制が以下のような場合、すなわち 2) 不動産などに対する物理的侵害（たとえばケーブル用の小箱の設

* 東京大学工学部都市工学科，助手・工博

** 東京大学工学部都市工学科 教授. 工博

Research Assoc., Dept. of Urban Engineering, University of Tokyo, Dr. Eng. Prof., Dept. of Urban Engineering, University of Tokyo, Dr. Eng. 
置）や、3)すべての経済的利益の剥奪など過度の負担、あるいは 4) 目的と規制行為の合理的なつながり（nexus）が欠如している、5） 個人への負担とそ扒によって公共が享受する利益の比例割合を行政 が示していない、6)私有財産の所有者が既に投資などを行っている とき、である。

1)については、HD の目的は歴史的環境保全あるいは美観が主要 な二つといえるが、各々 1978 年ベン・セントラル判決 ${ }^{2}$ (以下ベ ン判決)、1954 年バーマン判決3を通じて連邦最高裁によって認め ら打ている。

2)については連邦最高裁は、たとえ小さくとも不動産に対する物 理的な侵害はテイキングに匹敵するとしだ。HD では物理的侵害 に抵触する規定が想定しにくく、すなわち取り壊しの制限やデザイ ン上の規制等であるため、関連は薄いといえる。

3)はHDに最も深く関連するので次節で詳述する。

4)について連邦最高裁は、行政の目的とその目的を遂行するため の方法の間に、合理的な関係があることを要求している゙。

HDに関連しては、1941 年 City of New Orleans v. Impastato 判決 ${ }^{6}$ がある。ルイジアナ州ニュー・オーリンズのヴォー・カレ $\mathrm{HD}^{7}$ を対象としたものだった。中でも特に重要な「ナホホレオン・ハウス」 という歴史的建築物所有者は、裹庭に拡張工事を行つた。裹庭が通 りから可視範囲にあるために、工事には正式な手続きが必要とされ ていた。しかしこ挑を請しなかつたために罰金が科せら扒ること になった。こうした事態を受けて、同所有者が、規制の対象範囲で ある「外構 exterior」に正面だけでなく側面や裹面が含ま狆るこ とを不服として市を訴えた。ルイジアナ州最高裁は可視範囲を全て 規制の対象とするのは、地区の歴史的環境保全という条例の目的に 適台しているとして、市を支持している。

つまり HD における建築行為の制限やデザイン蜜査は、HD の目 的を遂行するための手段として合理的であることが認められている。

5)については、連邦最高裁は、規制による負担が個人にとつてど の程度のものであり、そ㧈によって公共が享受できる利益の度合い はどんなものか、を示すことを行政の責任と認めている゙。そのよ うな説明を行う財政的負担を考えると、HD を含む土地利用規制に 対して行政が消極的になるのではないか，と考えら扚”。

6)については、当該敷地等に対してキャピタル・ゲインを期待し て投資を行ったものに対して、何らかの補償を認めるという考え方 だ。既に開発に関連する様々な行政の手続きを経て、敷地所有者が

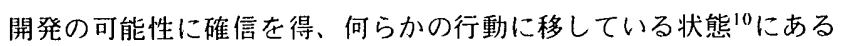
場合はテイキングとされやすい"。

HD に関連しては、既に指定さ扎ている HD では所有者は何らか の規制がかかることに対する認識があるものと考えられるので問題 にはなりにくいだろう。新たに指定を行う場合には、調査が始まり、 指定の可能性がある段階から告知などを行うことによって、そのよ うな問題は避けられよう。

2.2 テイキングとなる経済的目担の度合い

さて 3)に戻って、テイキングとなる経斎的負担の度台いについ て検討しよう。

ベン判決で示されてように最高最大限度の土地利用 (highest and best use）を字受すること自体が基本的には認められないと いう認識のもとで、それでもあまりにも過度の負担が為された場合
には正当な補償がなされるべきであると考えられている。全ての経 済的利益が損なわ扑ときはテイキングであることは明らかとされ るが、どれくらいがテイキングとなるのかについては程度問題であ る。程度の差は様々でケース・バイ・ケースとなっており、判決ご とに判断される ${ }^{12}$ 。たとえばベン判決は歴史的環境保全という公共 の福祉向上を目的とした場合に、個人（ある会社）に対して数百万 ドルの損害（開発していたならば得られただあろう利益）を課すこ とを認めたわけである。こ㧈に対しては、ベン判決に付された少数 意見13からも類推できるように、判断は分か机るところであった。

しかし、減少する価値が多大であっても、残される価值がゼロに 限りなく近いものでないかぎり、テイキングとは判断されてないい う考え方が浸透していく。

つまり、HD 内における取り壊しや大規模建築物への建て替えな どに対する制限は、通常、現状利用を禁止するものではないので、 テイキングとは判断さ扎にくいといえるい。

また、たとえ規制によって経済的な活用ができなくなったとして も即テイキングになるとは限らない。テイキングとして判断される ためには、取り壊しを望む所有者は、貨貸や売買をするための努力 を尽くしたことを証明しなけ执な゙ならいい。

このように HD 等の保全手法が取り壊しや建て替えの制限等を 通じて建築物所有者に強いる経済的負担は相当程度認められている といえよう。

\section{3 維持怘慢による取り䍜し}

さらに、HD 内の建築物は、外観の老朽悪化を防ぐことやメンテ ナンスが義務づけら扎、所有者が経費を負担する場合がほとんどで ある。この負担は、著しく重くない限り、またほとんどの場合重い とは認められてなが、保全条例等が一旦採択されてた限りは、その目 標達成に必要なものであり、テイキングではないと判断される。根 拠は、1975 年 Maher v. City of New Orleans 判決16である。 一旦、ヴオー・カレ条例の（歴史的環境保全という） 目的が適切なものとして受け入扎られたのであるならば、 建築物の外観を維持していくことも、条例の目標に到详 するためには合理的に必要なものである。（略）(しか し）ある状況下においては、条例のもとで行われる維持 管理の費用がテイキングをなすほど不合理になることも 起こりうる。

つまり、修復費用が過度に重い負担となり、その後の回収が見込 めないときは、取り壊しを支持する判決も出されている7。

このような状況の中で、現在、問題となっているのが、維持管理 の意慢による取り壊し（Demolition by neglect）である。

維持管理の義務を念ったがために、取り壊さずに現状利用を続け るための修復を行うには過度の負担を強いることになり、テイキン グとなってしまうという皮肉な状況が生じている。

そうなると、安全という見地からも取り壊しが許可さ扎るという 場合がでてきてしまう。1979 年、Wolk v. Reisen 判決18では、空 き家ゆえに放火されてた歴史的建築物の取り買しを求めたが、市が不 許可としたことで訴訟になった。当該住宅は、建築担当の地元公務 員が危険であると認めていた。裁判所は美観や歴史的関心よりも公 共の健康や安全が優先するとして、取り壊しの不許可を無効である とした。 
しかし、義務づけられている維持管理さえ行っていれば、このよ うな事態にはならなかったかもしれない。

白常的な維持管理と大規模な修復の違いは経費の額の差であり、 どこからがテイキングかという判断は、既述のように程度問題とい える。だからこそ、初期の段階からメンテナンスを強制的に行わせ るという、保全条例等の施行力が重要となってくるといえよう。メ ンテナンスの急慢があった場合には、载判所は修復の経済性をあま り重視すべきではないだろうという見解もある19。

\section{3. 台理的な基準の確立}

行政による土地利用規制には、合理的客観的な基準が必要となる。 2.1、4)でも触れたように、HD におけるデザイン審查等は有効で あると考えられ、実際に HD 内の質を保全あるいは高めるための 主要な手段はデザイン審査となっている。

HD の場合、歴史的であるという要素が合理性に大きく貢献して きた。しかし、特に 1960 年代頃から、HD が統一性の高い歴史的 環境から包括的な居住環境へと対象を広げるにつれて、基隻をさら に明確にする必要性が生じている。

現状では、法律的に十分で、かつ有効な基準の内容はケース・バ イ・ケースとなっている。

大きな裁量を与えられてでザイン審査を行う委員会組織などの能 力に対する疑念を背景にして、HD 指定や規制の合憲性が厳しく問 わ扎ているという状況分析が 1990 年代初頭にされている20。

詳細なガイドラインによって初めて基準の合理性が確立される一 方で、詳細化しすぎると画一的で単調な景観となってしまう。そ抔 では規制的な側面が強い美観規制から、創造的なものへと発展して 生まれてきたデザイン・ガイドラインの意義が失われててしまう。

このような状況において、デザイン・レビューによる判断の内容 （どんなデザインが良くて何が相応しくないのか等）はひとまずお いて、むしろそ打を決定する委員会のメンバー構成や選定方法、審 査の公開、通知など、いわゆる手続き上のデュー・ブロセスを充分 に徹底させる必要があることは論を待たない。開発権の移転に関す る論理を確立した法律家のコストニスが擁護したように゙1、美醜あ るいは適台不谪合のデザインそのものについてはコミュニティが主 体的に判断できるような手続きによって合理性は獲得できるのでは ないか。そのような手続きによって何を良しとし何を不許可とする のかという内容もまた緩やかな変化を許容しながら、合理的な基準 であることが確保さ扎ると考えら扎るのではないだろうか。

\section{4. 表現の自由}

連邦修正憲法第一条のもとで、HDに関連する表現の自由には二 通りがある。

\section{1 広告規制と表現の自由}

一つは、広告規制と表現の自由の問題である。広告の張り出し等 を制限することは、何を広告するかという内容の直接的規制ではな い。しかし、間接的に内容を制限することもあるのではないか、そ のことが表現の自由の侵害にならないか。こうした問題を避けるた めには、広告規制の目的を明確にするということと ${ }^{22}$ 、広告できる 場所を行政区域内に確保しておくこどが重要だ。

HD 内での広告規制に関しては、1941 年の City of New Orleans
v.Pergament 判決 ${ }^{2 \Lambda} 、 1993$ 年の Messer v. City of Douglasville 判決 ${ }^{25}$ がある。いず独も HD 内での全てのオフ・サイト、すなわち 当該広告が宣伝している商売などが行われている敷地の外に設置さ 打る看板を禁じる条例が支持されている。そ扎らの内容から以下の 三つの諸条件によって、HD 内の広告規制は裁判所によって支持さ れることが期待できよう。

1) HD の指定目的は表現の自由とは無関係に中立で、 内容が明確であること

2）しかも通常、広告は歴史的環境に依拠した地区の性 格を維持するという HD の目的を大きく損ないがちで あること

3) さらに市域の特定の地区内に限定されて㧍り、市域 内の他の場所では制限がないことが一般的である。

\section{2 建築物規制と表現の自由}

今ひとつは建築家の表現の自由である。いわゆる建築審査委員会 等が申請さ狆た建築デザインを意匠の観点から不許可とした場合や ガイドライン等で詳細に規制が為された場合に、建築家の創作活動 は制限される事態が生じる。連邦最高裁はこれまで一度も建築物を 表現の自由の対象であるとはしていない26。しかしこのような問題 が争わ扎たとすると、規制する側としては、ガイドライン等による 制限は、地勢等と同様、敷地に付与さ㧈た条件として当然考慮さ打 るべきであると主張することもできよう。また広告規制と同様に、

場所によって制限する場合とそうでない場合を設けることで、批判 をかわすことも考えられる。しかし、建築デザインは、特定の場所 だからこそデザインが為さ扎るはずである。つまり代替の場所で、 同じデザインが許されるからといって果たして、表現の自由を担保 したと言えるかどうか疑問である。

現状ではこうした表現の自由について、HD に関する大きな問題 としては議論さ㧈ていない27。しかし、今後、芸術の一分野として の建築の側面が注目された場合には、アメリカの憲法が表現の自由 に最大の価值を置くダブル・スタンダードであることを考えると、 慎重な対応が必要とされるかもしれない。

こうした将来の課題に対して、保全を専門とする建築家で法律家 でもある Byard は以下の点を指摘している28。すなわち增筑も含 めて既存の環境に何かを加えていくデザインにおいて重視すべきは 表現ではなくて意味である。新たなデザインの表現については柔軟 に対応していくべきであろう。しかしそのような表現は既存の環境 や建築物のもつ意味、特にそ机が民主的な手続きを経て公共の価値 として認められてたものであるならなおさらのこと、そのような意味 を尊重しなけ狆ばならないはずだ。

Byard は表現の自由と、建築として守るべき最低限の作法は矛 盾しないと論じているのである。

実際の建築家の反応を挙げてみよう。たとえばニューヨーク市で は市の歴史的環境保全条例のもと、歴史的環境保全委員会がデザイ ン審查を行っている ${ }^{29}$ 。市内で約 20000 棟の建築物に関する新築、 取り壊し、大規模な改築などに関して、この審査を受けなけれでな らない。具体的には、材料、色、空伜のプロホーション、コーニス、 リンテル等、あらゆる意匠に対して法的拘束力のある变更要請が為 される。デザイン審查が始まった 1965 年から 1970 年代初期にか けては、建築家から歴史的環境保全委員会に対して、意見書などが 
出されていたが、最近では一般的に、デザイン審査を前向きに受け 入れている。その理由としては、デザイン審査を行う歴史的環境保 全委員会という組織に対する信頼があること、優扎たデザインであ るならば許可されるという認識があること、さらに自分のデザイン も将来保全さ机る可能性があること、デザイン審査によって確かに 不適合なデザインが改善さ扎、結果としてニューヨーク市の町並み 景観が向上しているという実感があること、等が举げら扔 300

\section{5. 他の法建との調整}

5.1 他分野との連携の必要性

HD を指定して、そのもとで何らかの規制を加えていくためには、 同一地方自治体内での他の法律との整合性が欠かせない。

HD はソーニングとは別に「オーヴァーレイする地区」として運 用さ扎ていることがほとんどで、つまり既存のゾーニング条例によ る規制が有効である。そのためゾーニングと HD の間での調整が 問題となる。特に大都市において HD がいくつも指定さ扑、経済 的な開発压力が強い場合に深刻である。

1980 年代以降、地方自治体が総合的な（comprehensive）な計 画のなかに歴史的環境保全を考慮することを、州が要求する場合も 增えてきている31。その度合いは、義務づけるものから考慮を促す ものまで様々である。しかし整合性をはかるのは主に自治体の自助 努力によっているのが現状となっている32。

保全を目的亡する土地利用規制と他の法令の間に整合性があるこ とは、保全を推進するためだけでなく、開発者側にとっても利益が あるということが認めら㧈ている ${ }^{33}$ 。なぜなら最初から保全と開発 の位置づけが明確であるならば、開発計画が保全のために突然途中 で停止されててしう等の危険を避けることができるからだ。

更に、地方自治体が連邦政府からの補助金、特にUrban Development Action Grants（UDAG）のような用途の決定に地 方自治体の裁量が大きい補助金を得ようとするときに整合性がある ことは有利に働く。また、連邦政府によるブロジェクトを地方自治 体が反対しているとき、自治体内に整合性があるとその反対意見が 考慮さ扒やすい"31。

裁判所は、市民の総意によって、歴史的環境保全条例とゾーニン グ条例の調整がはから扎るとき、こ㧈を支持する動きが見ら犼る35。

ソーニング以外の問題としては、海岸治いの都市における海岸保 護が挙げら狆る。連邦による 1977 年の海岸沿ゾーン管理法（the Coastal Zone Management Act）に基づいて、海岸治いの自治体 は海岸の保護や開発に関わる計画を定めている。そ㧈らの計画は歴 史的な資源についても言及することとしており、いわゆる歴史的環 境保全部局によって進められている歴史的資源の保全との整台性が 必要である。

1969 年の国家環境保護法（NEPA）では州や連邦の行為を評価 すること、すなわち環境影響評価アセスメントを義務づけているが、 その際に考慮されるべき歴史的な資源が、歴史的環境保全法等のも とで指定を受けたものとどのような関係を持つべきなのか、明確な 規定がない33

また、様々な目的を持つ開発手法が採用されるるかで、新たな開 発手法の目的と歴史的環境保全が衝突を見せる場合が生じてきた。 具体的には Planned Unit Development が挙げられる。PUD は
自然環境を保護しつつ住宅地等を開発する手法であるが、PUD の もとで行わ㧈る開発行為は通常のブロセスとは異なる。通常の開発 行為は歴史的環境保全委員会等の審査を受けることが義務づけられ ているが、PUD の開発業者は義務が免除さ机ることがある37。そ の場合に PUD を審査する委員会が歴史的環境に考慮することがで きない、あるいはしない場合には歴史的環境が破壊される危険性を 伴う。

こうした状況を打開する方策として、保全条例の規制をソーニン グ規制よりも優先させる規則を設ける措置も行わ扎てる。あるい は、ゾーニングに関する州授権法に HD の規制に関する権限を与 え、ゾーニング条例の中にあらかじめ HD の規制を組み込む手法 もあり得る。都市保全官（Urban Conservator）等という特別職 を設け、歴史的環境保全分野そのものと、都市計画や他の分野との 連携が円滑に進むような努力も行われている゙3。 そして最も注目さ れているのが、以下に述べる包括的計画と保全計画である。

\section{2 包括的計画と保全計画}

\section{（1）包括的計画}

1980 年代半ばに包括的計画（a comprehensive plan） ${ }^{39}$ と従来 のマスタープランとの間に非常に重大な相違が見ら打ることとなっ た。個々の計画がマスターブランに従わなけ狆ばならない、という 記述は当然、従来からあった。しかし、1986 年の+ンフランシス コ市の住民投票によって可決さ扒たブロボジション M は、マスタ 一フランと一致する開発同意やソーニング条例でなけ扎ばそ挑らは 決定できないとしたのである。つまり包括的計画とその下位にある 計画や実施手段との一致（consistency）が義務づけら扑たの゙あ $3^{10}$ 。

包括的計画は、密度の高い都心部等既成市街地内部の歴史的環境 保全だけでなく周辺部に広がる田園地域や自然環境も含めて、開発 と保全のバランスを包括的に捉える考元方を根底に据えているれ。

このような包括的計画が普及した12背景には、ソーニング条例を はじめとする都市部での土地利用規制と保全計画との調整が必要に なってきたことに加えて、自然環境へのスプロールの防止等にみら 犯る都市周辺部の問題が深刻になってきたこと、成長管理政策に代 表されるる物理的以外の視点を持つ広い意味での環境問題への関心の 広がりを考えることができよう。

(2) 保全計画

保全計画（preservation planning）は、包括的計画に考慮され るべきひとつの柱として位置づけられる。包括的計画は、住宅政策 や交通計画等の他の分野における価值と同等の価値を保全計画に置 き、こ阮らを独立して並立させる ${ }^{43}$ 。保全計画は 1960 年代に入っ てから、地方自治体の歴史的環境保全の局面において設けら扎てい った。この分野における最も重要な進歩であると評価さ打ている11。

現時点において、地域の開発の状態やコミュニティの大きさ、既 存のゾーニング条例や市民の意问等、諸処の条件が異なるため、保 全計画は様々であり、一般化して語ることは難しい。しかし保全計 画の目的として少なくとも、保全の目標を明確にし、コミュニティ に対して行政の资勢を前もつて示すことでテイキング等の問題を回 避し、政治的な理解を得ること等は共通している15。

そしてこれらが一致義務を持つ包括的計画において位置づけられ ることで、実現されていく道筋が確保されているのである。 


\section{6. 結論〜 HD から導かれる都市保全の課題と展望}

さて、以上述べてきたことをまとめると、HD の現状の法的論点 と課題は、以下の四つに整理できる。

1)テイキングに抵触しかねない維持㤐慢による取り壊し問題。こ 才てについては、維持管理を徹底させるには行政の予算上の問題もあ るが、維持急慢が認めら扎た場合の修復費用を、そのままテイキン グ判断の材料としない心゙きであろう。

2)合理的な基準の確立の問題。こ狆については、審査等の対象と するデザインに対して、内容の統一を図るために硬直的なガイドラ イン等によって美醜の価値観を押しつけるのではなくて、民主的な 手続き（公開性や委員の選定、参加のあり方）によって台理性を獲 得することが考えられる。

3)ブザイン審查と建築家の表現の自由の問題。これについては、 一定の民主的手続きを経たうえで指定が行わ狄てることを鑑みれ ば、そのような建築物あるいは場所には重い公共性が意味づけら才 ていると考えら扑るのえに、そ㧈に対する考虑したうえでの建築 家の表現の自由が認めら犼る゙きといえる。

4)他の法律との調整については、全体の中で保全を位置づける動 きと保全計画の中で、他との関係を積極的に模索していく動きの双 方を今後も強化していくべきだろう。

以上、得られた結論はいずれも普遍的な都市保全のあり方に対す る示唆として有効であると考える。

文末注

' Exploring Inc.による調査でHD を採用している地方自治体は 95\%にのぼり、他の手法よりも圧倒的に多い。

${ }^{2}$ Penn Central Transportation Co. v. City of New York, 438 U.S. 104 (1978)

${ }^{3}$ Berman v. Parker, 348 U.S. 26 (1954)

${ }^{4}$ Loretto v. Teleprompter Manhattan CATV Co., $102 \mathrm{~S}$. Ct. 3164(1982)、連邦最高裁はケーブルテレビ会社があるアハートに コード等の装置を設置することを認めたニューヨーク州の条例を無 効とした。たとえ $1 / 8$ 立方フィートの侵害でも、これを永久的に 侵害することはテイキングであるとした。

"Nollan v. California Coastal Commission, 438 U.S. 825 (1987)

${ }^{6}$ City of New Orleans v. Impastato, Supreme Court of Louisiana. 198 La. 206, No. 36199 (1941)

${ }^{7} 1937$ 年にアメリカでも極初期の HD として指定された。

${ }^{8}$ Dolan v. City of Tigard, 114 S.Ct. 2309(1994)

91926 年ユークリッド判決 Village of Euclid v. Ambler Realty Co., 272 U.S. 365(1926)によってソーニングの合憲性が認めら才 て以来、土地利用規制に関する訴訟がテイキングという理由で連邦 最高裁まで上訴さ扎たことは 1978 年ベン判決までなかった。テイ キングが認められにくかったからだ。しかし、1987 年にはテイキ ング三部作と蓄わ杞る三件もの訴訟が連邦最高裁において起こった。 また、テイキング立法の動きも見られる。最近は、アメリカ全体に 政府の規制よりも個人財産権の豙受が重んじら打る傾向がある。 11)開発許可の発行だけではこうした状態とは認められない。 1 "900 G Street Associates v. Department of Housing 判決 430 A. 2d 1387(D.C. 1981)では、前所有者が既に歴史的建築物の取り壊 しを市から拒否さ扎た後に、現所有者は当該建築物を購入している こと、市も出版物などを通じて指定建築物に関する情報提供の努力 を行っていたことより、「Investment backed expectations」に は当たらないとして、取り壊しの許可を拒否した住宅局を支持した。 ${ }^{12}$ Pennsylvania Coal Co. v. Mahon, 260 U.S. 393(1922)で連邦 最高裁は、規制に対する補償の有無は、規制による価値の減少具合 によるものだが、普遍的な割合では説明できない、とした。 Florida Rock Indus v. United States, 791 F 2d 893, 893 (D.C. Cir. 1986)も「(テイキングでなく合理的な負担として）許さ扎る、
市場価格の下落の程度を決める公式はない」としている。 ユークリッド判決では 1 エーカーにつき約 1 万ドルだった地価が 規制によって 2,500ドルになり約 75\%の減少となった。 Hadacheck v. Sebastion 判決（239 U.S. 394, 1915）では当該敷 地の経済的価值が 80 万ドルから 6 万ドルへ、約 $90 \%$ の減少にも 関わらず連邦最高裁はテイキングと認めなかった。

Keystone Bituminous Coal Ass'n v. De Benedictis 判決 (480 U.S. 470,1987）でも2,700万トンの石炭発掘権を認めら扎かった。 ${ }^{13}$ Rehnquist 裁判官らによる少数意見は、次のように述べている。 寸なわち、ベン会社はあまりに素睛らしい駅を設計してしまったが ために、私有不動産の開発利用が制限されるのは不合理だ。新たな 活用に対するゾーニングなどの制限と異なり、歴史的環境保全を目 的とする本規制は、過去の用途と規模にしばりつける。さらに、当 該規制によって被る数百万ドルの損害は、他の市内の歴史的建造物 等が健全に守られたからといって、あるいはTDRにより多少の開 発ができるからといって、補償されるとはいえない。

11ベン判決では指定が駅舎としての現状利用を妨げるものでないこ とがテイキングを認めない主要事由となっていた。

に初めて証明の責任が所有者側に課されたのは、HD とは関係ない が、Goldblatt v. Hempstead 判決(369 U.S. 590 1962)だった。 連邦最高裁は水面下の掘削を禁じる条例を支持した。その理由は同 条例が地価を下げたという証拠が所有者によって提出されてていない からだった。

900 G Street Associates v. Department of Housing 判決 (430 A.2d 1387 D.C. 1981）でも、歴史的建築物の取り壊しの許可を無 効とした市が支持されれた。その理由として、所有者は既存建築物で は合理的な見返りが期待できないことを証明しなけ扑ばならないが、 賃貸や最小限の修復による存続の可能性が見極めら饥ていないし、 所有者が主張する額よりも安く修復ができると考えられるるとした。 テイキングや HD とは直接関連しないが、Dempsey v. Boy's Club 判決（558 S.W. 2d 262 Mo. Ct. App. 1977）も、行政が歴史的建 築物の取り買しに対する許可を発行する前に、技術的経済的に当該 建築物の存続は非現実的であることを所有者が証明するように条例 は要求できるという考えを示した。

Citizens Comm. To Save Historic Rhodes Tavern v. District Columbia Dep't of Housing \& Community Dev. 判決 (432 A.2d 710,718 (D.C.) cert. Denied, 454 U.S. 1054 1981) でも、開発 業者は歴史的建築物を保存するためのすべての代替案を考慮したこ とを証明することが要求さ㧈た。

Lubelle v. Rochester Preservation Board 判決 No. 3481-85 (N.Y. Sup. Ct. June 14, 1988)は、当該歴史的建築物に対する購買 の申し出が実際にあったことを指摘し、指定によって経済的な活用 が損なわれたとは言えないとして、取り壊しの不許可を支持した。 Atlanta Ten v. City of Atlanta 判決 (No. 1:88-CU-157-HTW N.D. Ga. Jan. 10, 1990）でも、指定済みの歴史的アハートメント 建築の取り壊し許可を出さなかった市が支持さ机た。当該建築物は 長年廃屋で建築的重要性が高いとは考えら扎ていなかったが、マー ガレット・ミッチェルが風と共に去りぬ」を書いたアハートであ つたため、歴史的重要性が認めら机ていた。所有者は「highest and best use」ができないことしか証明できていないと指摘された。

${ }^{16}$ Maher v. City of New Orleans, 516 F. 2d 1051 (5th Cir. 1975) ${ }^{17}$ Lafayette Park Baptist Church v. Scott 判決 (553 S.W. 2d 856, Mo. App. 1977）では HD 内の劣化した状態の教会を取り壊す許 可が市によって拒否さ扎たことを受けて、第二審で市の拒否は無効 とされた。地方裁判所は、 5 万ドル以上の修復経費は、修復した教 会から所有者が得ら扎る合理的な見返りを超えるものであり、こう した場合には取り壊しを許可するとした。

同様に、Beneson v. United States 判決 (548 F. 2d 939, 947 Ct. Cl. 1977）では、試算さ扎た修復費用と、その後に期待できる収入を 考虑し、ホテルである歴史的建築物の取り壊しを認めないのはテイ キングであると結論した。

Broadview Apartments Co. v. Commission for Historical \& Architectural Preservation 判決 (443 A. 2d 1214 Md. App. Ct. 1981）でも、歴史的建築物の取り壊しを市が不許可としたことを 無効とした。その理由は、開発者側が複数の専門家によって修復費 
用を見積もった上で過度な負担であると結論しているのに対して、 行政側は一社の、しかも負債等を考慮に入れないいボートに頼った、 誤った判断をしているからだとした。

${ }^{18}$ Wolk v. Reisen, 413 N.Y.S. 2d 60, App. Div. (1979)

${ }^{19}$ Logue, p.759

${ }^{20}$ National Trust for Historic Preservation, p.2

${ }^{21}$ Costonis, Icons \& Aliens 等の著作の主張である。

22電気促進のための広告規制を無効とした Central Huclson Gas \& Elec. Corp. v. Public Serv. Comm'n 判決 (447 U.S. 667 1980)

では連邦最高裁は以下の手続きによって広告規制と言論の自由との 関倸を見極めるべきとしている。1)表現内容が修正憲法第一条で守 られるるべきものかどうか。商業広告の場合は、合法的活動で誤解を 生じさせるようなものでないことが必要とされる。2)同時に政府が 規制によって详成しようとしている目的が本質的なものかどうか。 1)2)共に匹敵するなら、3)規制が政府の目的を直接的に推進するも のかどうか。4)規制の度合いが必要以上に厳しくないかどうか、と いう四段階である。この手続きによる見極めは以降の判決で広く採 用されているが、特に4)の解釈が実際には論点となることが多い。 Metromedia, Inc. v. City of San Diego 判決 (26 Cal. 3d 848, 610 P.2d 407, 164 Cal. Rptr. 510 (1980), reversed on other grounds, 453 U.S. 490 1981）では、3)が論点となった。オフ・サイトの商 業看板を全市域で禁止し既存の看板に関しても一定の猶予期間（場 所に応じて 90 日から 4 年) の後撤去することを要求するサン・デ イエゴ市の条例は違憲であると、商業看板の所有者かつ生産者が訴 えた。連邦最高裁は、市の条例は「交通事故を減らし、コミュニテ イの外観を改善し、そ扒によって不動産価値を上昇させる」という 目的をもって定めら㣙たもので、ボリス・ハワーの行使目的として 適つているとし、支持した。この討論の中で、原告は全市域で禁止 することは言論の自由を認めないことだと主張している。 City of Los Angeles v. Taxpayers for Vincent 判決 (466 U.S. 789, 1984）では、禁止さ扎た看板（sign）の内容が市議会議員立 候補者の支援という政治に関わるもので、言論の自由に直接関係す るものと考えられる。しかし連邦最高裁は、言論の自由の侵害とい う原告の主張を退け、視覚的に乱雑であるという理由で看板を禁じ る市の条例を支持した。ここで重視された点は、看板は情報伝達の 方法として視覚的に不快であること、そして問題となっている条例 は看板よりも安上がりにすむビラ等の手法を禁じてはいないこと、 という二点であった。すなわちコストが余計にかからない別の方法 で、同じ目的を達成できるのだから、市の規制は言論の自由を侵し ていないとした。そして逆に政治に関してのみ例外として取り扱う と、憲法で禁止さ㧈ている、内容の差別となる恐狆があるとした。 ${ }^{23}$ PA Northwest Districutors, Inc. v. Township of Moon 判決 （584 A 2d 1372 Pa., 1991）は、ボルノ・ショップの市域全域禁 止規制を無効とした。

一方、City of Renton v. Playtime Theaters, Inc.判決 (4 75 U.S. 41 1986)において連邦最高裁は、市の $5 \%$ に匹敵する 520 エーカ 一については制限がなかったので、劇場の立地規制を合憲とした。 ${ }^{21}$ City of New Orleans v. Pergament, 5 So. 2d 129 La. (1941)

${ }^{25,5}$ Messer v. City of Douglasville, 975 F.2d 1505 (11th Cir. 1992), certified denied, 113 S. Ct. 2395 (1993)

${ }^{26}$ Costonis, p.94

${ }^{27}$ たとえば Logue は、論文の中で宗教の自由としての第一条は述 ベているが、広告や建築家の表現の自由には触扟ていない。

${ }^{28}$ Byard、p.159

29 ニューヨーク市の保全に関しては、窖田・西村(2000)を参照。 30 ニューヨーク市の建築家の傾向は、コロンビア大学大学院歴史 的環境保全学部助教授のドロシー・マイナーーの講義、市で活躍して いる建築家であるフランソワーズ・ボラックとフィリッブ・スミス へのインタビュー、現地で行わ扎てるシンホジウムでの議論や新 聞等から総合的に判断した。

${ }^{31}$ Duerksen, p.44

32 A-S-Passociation v. City of Raliegh 判決(258 S.E. 2d 444, N.C. 1979)は条例の台憲性を認めるに当たって整合性を前向きに 評価している。

${ }^{33}$ Duerksen, p.45
31たとえば自治体が総合的な保全計画に基づきダウンタウンを HD として指定していると、HD 内で州がメイン・ストリートを拡幅し て幹線道路を建設するブロジェクトを進めようとするとき、連邦政 府は同ブロジェクトに対して補助金を出すことを訾躇すると指摘さ れている。Duerksen、p.45

35 シカゴでは 1980 年に市議会がダウンゾーニングを行った。当時、 シカゴ市は歴史的環境保全条例により、歴史的環境保全委員会がル 一ブと㭔ばオる歴史的な業務地区内での高層ビルの指定を推萀し、

市議会も承認していた。しかし、現行ソ゚ーニング条例のもとで許容 さ扔る、より高いビルによる再開発計画が開発業者によって申請さ 扒ると、市議会はやはり許可していた。こうした状況を経て、市議 会は保全とソーニングとの調整の重要性を認識し、ループの北部を 中心にしたダウンゾーニングを採択した。これては所有者によって所 有権の侵害であるとして訴えら扎た。Amdur v. City of Chicago, 638 F.2d 37 (7th Cir. 1980)判決はダウンゾーニングを支持した。

${ }^{36}$ Duerksen, p.58

${ }^{37}$ Miller、p. 1

${ }^{38}$ たとえばシアトル市やシンシナ゙ッティ市。Duerksen、p.58 39包括的計画と指すものは州によって呼び名が異なる。例えばカリ フォルニア州では general plan が包括的計画といえよう。秋本 p.176、福川 p.197

10)秋本 p.176、福川 pp.198 199

川包括的計画は、新規開発に対する圧力がどのように生じているの か、都市内部と周辺部の経済的な衰退の原因は何か、という点に配 慮して作られる。主に既存のソーニング条例を土台として、密度、 敷地、デザインなどの各要素を強調しながら特別なソーンを重祆た り、行政手続きを加えたりしたものが多い。Miller、pp..2041-2042 12 大野は、本論文中のなかで「包括的計画」としたものを「マス ターブラン」という名のもとで説明している。「マスターブラン」 が義務づけら机ている州、加えて consistency も義務づけら扎 いる州などが増えており、consistency の直接的な義務づけがなく とも「マスターブラン」と具体的規制手段の間に合理的な関係性を 求める傾向が訴訟の際には見ら扟るとしている。大野 pp.172〜177 ${ }^{13}$ White, p.1

11 Miller, p.2041

${ }^{15}$ White, p. 1

口参学文鲇

Byard, Paul Spencer. (1998) The Architecture of Additions: Design and Regulation. New York: Norton.

Costonis, John J. (1989) Icons and Aliens: Law, Aesthetics, and Environmental Change. Urbana and Chicago: University of Illinois. Duerksen, Christopher ed. (1983) A Handbook on Historic Preservation Law. Conservation Foundation \& National Center for Preservation Law.

Exploring the Metropolis Inc. (1990) Hindsight and Foresight: Planning to Project and Guide Special Neighborhood. New York: Exploring the Metropolis Inc.

Hinshaw, Mark L. (1995) Design Review. Washington: the Planning American Association.

Logue, Thomas W. (1990) "Avoiding Takings Challenges While Protecting Historic Properties From Demolition". in Stetson Law Review, Vol. XIX, Number 3, Summer

Miller, Julia Hatch.(1987) "Coordination of Historic Preservation and Land Use Controls: New Directions in Historic Preservation Regulation", in Preservation Law Reporter, Winter 1986/87, Vol. 5, No. 4, 5 PLR 2041

National Trust for Historic Preservation, (1992) "Reviewing New Construction Projects in Historic Areas". Preservation Information, Washington: National Trust for Historic Preservation. No.62.

White \& Roddewig. (1994) Preparing a Historic Preservation Plan. APA Report, 450

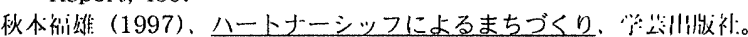

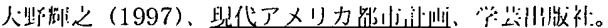

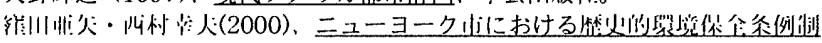

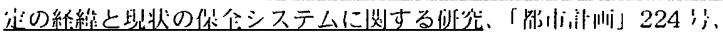

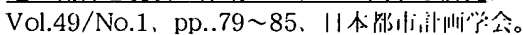

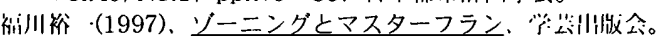

